\title{
Magnetic Ultrathin Tissue Sections for Ease of Light and Electron Microscopy
}

German Koestinger, Daniel During, Simone Rickauer, Vanessa Leite, Homare Yamahachi, Gabor Csucs, Richard HR Hahnloser

This manuscript has been removed as the result of a ruling by ETH Zurich. 